\title{
Spontaneous Production of an Interleukin 1-like Factor by Cloned Rheumatoid Synovial Cells in Long-term Culture
}

\author{
Makoto Goto, “ Minoru Sasano, Hisashi Yamanaka, Nobuyuki Miyasaka, Naoyuki Kamatani, Kazuhiko Inoue, \\ Kusuki Nishioka, and Terumasa Miyamoto* \\ Institute of Rheumatology, Tokyo Women's Medical College, *Department of Medicine and Physical Therapy, Faculty of Medicine, \\ University of Tokyo, Tokyo, Japan
}

\begin{abstract}
We have cloned adherent synovial cells from rheumatoid synovitis. These can be generally divided into three types, including cells that have the characteristic features of dendritic cells (DCs), macrophagelike cells (MCs) and fibroblastlike cells (FCs), as classified by morphology and immunofluorescent staining. The cloned cells were able to divide and were cultured for up to 11 mo without any significant morphological changes. All the cloned cells were HLA-DR ${ }^{+}$after $\boldsymbol{\gamma}$-interferon treatment. Spontaneous production of a factor with interleukin 1 activity by the cloned cells was detected even after long-term culture (the ability, on a per cell basis, being in the following order: DC $>$ MC $>$ FC). These synovial cells may be important for bony destruction in rheumatoid joints.
\end{abstract}

\section{Introduction}

Bony resorption is one of the major pathological features in chronic inflammatory joint diseases such as rheumatoid arthritis (RA) ${ }^{1}(1)$. This process is related to collagenase and prostaglandin $\mathrm{E}_{2}\left(\mathrm{PGE}_{2}\right)$ present within the joints. Interleukin 1 (IL-1) has been suggested as a mediator in stimulating bone resorption (2). IL-1 itself stimulates the release of calcium from the bone and also induces degenerative substances such as collagenase and $\mathrm{PGE}_{2}$ from the synovial cells at sites of bony destruction $(3,4)$.

Dendritic cells (DCs), abundant in RA synovium and synovial fluid, are potent stimulators of the autologous mixed leukocyte reaction (5-8) and also producers of IL-1 in response to mitogens (9). A central role for the DCs in conditions such as rheumatoid synovitis has been proposed (8), and the origin of the DCs has been a subject under study (10). Some evidence indicates that the precursor of DCs may be the synovial fibroblasts, stimulated by substances of chronic inflammation (11).

Address reprint requests to Dr. Nishioka, Director, Institute of Rheumatology, Tokyo Women's Medical College, Shinjuku NS Building 3F, 2-4-1 Nishi-Shinjuku, Shinjuku-ku, Tokyo, 160, Japan.

Received for publication 2 December 1986 and in revised form 27 April 1987.

1. Abbreviations used in this paper: $\mathrm{DC}$, dendritic cell; FC, fibroblastlike cell; FITC, fluorescein isothiocyanate; IL-1, interleukin 1; MC, macrophagelike cell; 2ME, 2-mercaptoethanol; MoAb, monoclonal antibody; $P E$, phycoerythrin $B ; P E_{2}$, prostaglandin $E_{2} ; R A$, rheumatoid arthritis.

J. Clin. Invest.

(c) The American Society for Clinical Investigation, Inc.

$0021-9738 / 87 / 09 / 0786 / 11 \quad \$ 2.00$

Volume 80, September 1987, 786-796
However, experiments so far have been done by using a heterogenous mixture of adherent synovial cells including DCs, macrophagelike cells (MCs) and fibroblastlike cells (FCs).

Therefore, we undertook this study to clone the adherent synovial cells to determine how many kinds of different cells are present in the synovial membrane, if the different types of cells are morphologically interchangeable, and finally whether the cloned synovial cells could release IL-1. The cloned adherent synovial cells consisted mainly of the cells with the characteristic features of FCs, DCs, and MCs as judged by morphology and function. These cloned cells were able to divide and release IL-1-like factor spontaneously.

\section{Methods}

Preparation of synovial cells. The synovial cells used in this study were obtained by arthroscopic synovectomy from the knee joints of five patients with classical or definite RA. All of the patients were receiving nonsteroidal antiinflammatory agents; additionally, some were on small doses of corticosteroids. After removing the adipose tissues, the specimens were minced, transferred to sterile plastic tubes, and then washed three times in phosphate-buffered saline (PBS). The minced synovial tissues were treated with PBS $+0.25 \%$ trypsin for $40 \mathrm{~min}$ at $37^{\circ} \mathrm{C}$, and then the cells in the supernatants were collected. The cells were washed three times in PBS and finally suspended in HAM F-12 medium (Gibco Laboratories, Grand Island, NY) supplemented with $10 \%$ fetal bovine serum (FBS), $5 \times 10^{-5} \mathrm{M}$ 2-mercaptoethanol (2ME), $100 \mathrm{U} / \mathrm{ml}$ of penicillin, and $100 \mu \mathrm{g} / \mathrm{ml}$ of streptomycin. FCs comprised both $\sim 40-50 \%$ and DCs $\sim 5 \%$ of the total cell population from the original synovial specimens both culture.

Cloning of synovial cells. Synovial cell cloning was performed by limiting dilution (12). The cells were suspended in the medium at a density of 2 cells $/ \mathrm{ml}$. $150 \mu$ l of the samples was then placed in 96-well, flat-bottomed culture plates $\left(0.6 \mathrm{cell} /\right.$ well) and incubated at $37^{\circ} \mathrm{C}$ in a humidified atmosphere with $5 \% \mathrm{CO}_{2}$. The day following the cloning of the synovial cells, each well was carefully examined with a microscope to see if only a single cell existed. If two or more were observed, the well was categorized as a "poly-clone" well (Table I). After $30 \mathrm{~d}$ of primary culture, each cloned cell was recloned at a ratio of 0.3 cell/well. Cells were passaged once in 2-4 wk by treating adherent cells with $0.05 \%$ trypsin for $5 \mathrm{~min}$ at room temperature and then placing five cells in each well after washing.

Characterization of the cloned cells including immunofluorescence, IL-1 activity and phagocytosis was done as described below after 7 mo of culture. Contamination by Mycoplasma was excluded by the method described by McGarrity et al. (13).

Characterization of the cloned cells by immunofluorescence. The recloned cells were classified morphologically by direct observation with phase-contrast microscopy and the immunofluorescence test using fluorescein isothiocyanate (FITC) or phycoerythrin B (PE) plus monoclonal antibodies (MoAbs). All the MoAbs used in this study were obtained from commercial sources; their specificities are listed in Table II. 


\begin{tabular}{|c|c|c|c|c|c|c|c|}
\hline \multirow[b]{2}{*}{$\begin{array}{l}\text { Patient } \\
\text { initials }\end{array}$} & \multirow[b]{2}{*}{ Age } & \multirow[b]{2}{*}{ Sex } & \multirow[b]{2}{*}{$\begin{array}{l}\text { Days in } \\
\text { culture* }\end{array}$} & \multicolumn{4}{|c|}{ No. of cloned well per 96 wells } \\
\hline & & & & DC & MC & FC & $\begin{array}{l}\text { None or } \\
\text { polyclone }\end{array}$ \\
\hline I.K. & 71 & $\mathbf{F}$ & 8 & 11 & 11 & 64 & 10 \\
\hline K.S. & 63 & $\mathbf{F}$ & 20 & 2 & 1 & 5 & 8 \\
\hline N.H. & 49 & $\mathbf{F}$ & 7 & 1 & 2 & 21 & 72 \\
\hline Y.T. & 43 & $\mathbf{M}$ & $30^{\S}$ & 4 & 12 & 14 & 66 \\
\hline M.N. & 39 & $\mathbf{F}$ & $30^{\S}$ & 4 & 20 & 36 & 36 \\
\hline
\end{tabular}

* Morphological determination was done on the indicated days in culture. $\quad$ ‡n the day after the cloning of the synovial cells, each well was carefully examined to see if only a single cell existed. If there was no cell or two or more cells were observed, the well was categorized into a "None or polyclone" well. "After $30 \mathrm{~d}$ of the initial cloning, each cloned cell (DC, MC, and FC) was recloned at a ratio of 0.3 cell/well. The morphological determination after 2 wk of recloning showed the same pattern as the respective original cells.

The recloned cells in 96-well culture plates were washed with PBS-2\% FBS for $5 \mathrm{~min}$ at $37^{\circ} \mathrm{C}$ and fixed by air-drying for $30 \mathrm{~min}$ at room temperature. After gentle washing with PBS-2\% FBS, the cells were incubated with $10 \mu$ l of MoAbs (10 times diluted with PBS-2\% FBS) for $30 \mathrm{~min}$ at $4^{\circ} \mathrm{C}$ and rinsed in PBS-2\% FBS. If necessary, they were also incubated with $10 \mu \mathrm{l}$ of FITC-conjugated goat anti-mouse IgG or IgM (Cappel Laboratories, Westchester, PA) for 20 min at $4^{\circ} \mathrm{C}$ as described previously (14). After washing with PBS-2\% FBS, the cells were examined by fluorescence microscopy.

As $\gamma$-interferon is known to augment the expression of DR antigen on the cell surface, the cells were treated with $100 \mathrm{U} / \mathrm{ml}$ of recombinant $\gamma$-interferon (Shionogi, Tokyo, Japan) for $48 \mathrm{~h}$ at $37^{\circ} \mathrm{C}$ in the case of HLA-DR MoAb staining. For antivimentin MoAb staining, the cloned cells were fixed in methanol at $-20^{\circ} \mathrm{C}$ for $10 \mathrm{~min}$, rinsed in PBS, incubated with PBS + 20\% FBS at room temperature for $10 \mathrm{~min}$, and washed with PBS. They were then incubated with $10 \mu \mathrm{l}$ of antivimentin $\mathrm{MoAb}$ at $37^{\circ} \mathrm{C}$ for $1 \mathrm{~h}$, rinsed in PBS, incubated with $10 \mu \mathrm{l}$ of horseradish-peroxidase conjugated goat-anti-mouse IgM at room temperature for $30 \mathrm{~min}$, rinsed in PBS, incubated for 5 min with 3,3'-diaminobenzidine tetrahydrochloride (Wako Pure Chemical Co., Tokyo) and then washed in PBS.

Phagocytosis of charcoal particles. Charcoal particles (Norit A, Wako, Japan: particle size $<6 \mu \mathrm{m}$ ) were used to detect phagocytosis at a cell/particle ratio of 1:100. The cloned cells in 96-well culture plates (100-1,000 cells/well) were mixed with an appropriate number of charcoal particles for $24 \mathrm{~h}$ at $37^{\circ} \mathrm{C}$ in humidified air $+5 \% \mathrm{CO}_{2}$. Silica particles (Silicon Dioxide; Sigma Chemical Co., St. Louis, MO) were

Table II. Characteristics of Monoclonal Mouse Anti-human Antibodies

\begin{tabular}{|c|c|c|c|}
\hline MoAbs & $\begin{array}{l}\text { Ig } \\
\text { subclass }\end{array}$ & Source & Specificity \\
\hline $\begin{array}{l}\mathrm{OKT}_{3} \\
\mathrm{OKB}_{7} \\
\mathrm{OKM}_{1}\end{array}$ & $\begin{array}{l}I_{g G} G_{2 a} \\
I G_{2 a} \\
I g G_{2 b}\end{array}$ & $\begin{array}{l}\text { Ortho Diagnostic } \\
\text { Systems, Inc. } \\
\text { Raritan, NJ }\end{array}$ & $\begin{array}{l}\text { T cells } \\
\text { B cells } \\
\text { Monocytes, } \\
C_{3} \text { bi receptor }\end{array}$ \\
\hline $\begin{array}{l}\text { OKDR-FITC* } \\
\text { Leu } \mathrm{M}_{3}-\text { FITC }^{*} \\
\text { Leu 15-PE } \\
\text { anti-Vimentin }\end{array}$ & $\left.\begin{array}{l}\mathrm{IgG}_{2 \mathrm{a}} \\
\mathrm{IgG}_{2 \mathrm{~b}} \\
\mathrm{IgG}_{2 \mathrm{a}} \\
\mathrm{IgM}\end{array}\right\}$ & $\begin{array}{l}\text { Becton-Dickinson \& Co. } \\
\text { Mountain View, CA } \\
\text { Transformation } \\
\text { Research Inc. } \\
\text { Framingham, MA }\end{array}$ & $\begin{array}{l}\text { HLA-DR } \\
\text { Monocytes } \\
\text { C }_{3} \text { bi receptor } \\
\text { Vimentin } \\
\quad \text { filaments }\end{array}$ \\
\hline
\end{tabular}

* FITC-conjugated monoclonal antibody.

‡ Phycoerythrin B (PE)-conjugated monoclonal antibody. also used at a final concentration of $100 \mu \mathrm{g} / \mathrm{ml}$. The particle size distribution of the silica particles was $0.5-10 \mu \mathrm{m}$ and $\sim 80 \%$ of the particles were between 1 and $5 \mu \mathrm{m}$. Nonspecific esterase staining was performed by the method of Koski et al. (15).

Assay of IL-1. To detect IL-1-like activity in the supernatant from the cloned cells in the presence or absence of possible stimulants (2ME, FBS, $\mathrm{PGE}_{2}$, charcoal, or silica particles), the supernatants were collected after 48-h $\left(\mathrm{PGE}_{2}\right)$ or 24-h (2ME, FBS, charcoal, and silica particles) stimulation (if stimulants were used), centrifuged, and kept at $-20^{\circ} \mathrm{C}$ before use. The cultures were done with or without polymyxin B (final concentration: $12.5 \mu \mathrm{g} / \mathrm{ml}$; Sigma Chemical Co.) in the medium. Some of the samples were dialyzed against PBS for $24 \mathrm{~h}$ to remove $\mathrm{PGE}_{2}$, though $\mathrm{PGE}_{2}$ detected by radioimmunoassay revealed relatively low $\left(10^{-8}-10^{-9} \mathrm{M}\right)$ concentrations in another experiment.

Assay of IL-1-like activity was performed by a conventional thymocyte costimulation assay (16). An ultrapure human IL-1 standard was purchased from Genzyme Corp. (Boston, MA; sp act: $100 \mathrm{U} / \mathrm{ml}$; sp act: $8 \mathrm{U} / \mathrm{pg}$ protein; $\mathrm{T}$ cell growth factor contamination $<1 \%$; interferon contamination $<1 \mathrm{U} / \mathrm{ml}$ ). 5-6-wk-old $\mathrm{C}_{3} \mathrm{H} / \mathrm{HeJ}$ mice were sacrificed by cervical dislocation. Their thymuses were minced and pressed through a stainless steel sieve, washed twice in complete medium and suspended with $2 \times 10^{-5} \mathrm{M} 2 \mathrm{ME}$. Next, $100 \mu \mathrm{l}$ of thymocytes, $80 \mu \mathrm{l}$ of the cultured supernatant samples and $20 \mu \mathrm{l}$ of a suboptimal concentration of phytohemagglutinin (final concentration: 0.1 $\mu \mathrm{g} / \mathrm{ml}$ : Difco, Detroit, MI) were placed in triplicate wells in 96-well, flat-bottomed culture plates and incubated for $72 \mathrm{~h}$ at $37^{\circ} \mathrm{C}$ in a humidified atmosphere with $5 \% \mathrm{CO}_{2}$. The cultures were pulsed by adding $0.5 \mu \mathrm{Ci}$ of $\left[{ }^{3} \mathrm{H}\right]$ thymidine to each well during the final $8 \mathrm{~h}$ of culture. Cells were harvested onto Fiberglas paper using an automatic cell harvester and placed in scintillation fluid. The ${ }^{3} \mathrm{H}$ content was determined by a liquid scintillation counter. The IL-1 activity in units per milliliter of supernatant samples was calculated by comparison to a standard curve, obtained by using the ultrapure human IL-1 standard. Interleukin 2 activity was also measured using the interleukin 2-dependent cell line, B6, as described previously (17). No interleukin 2 activity was detected in any supernatant from the cloned synovial cells.

Effects of $P G E_{2}$ on the cloned FCs. $\mathrm{PGE}_{2}$ is produced at the site of inflammation in such conditions as rheumatoid synovitis (reference 1 and manuscript in preparation). The effects of $\mathrm{PGE}_{2}$ were examined on the cloned FCs as regards their possible morphological changes into DC and production of an IL-1-like factor. The cloned FCs $(\sim 1,000$ cells/well) in the 96-well culture plates were treated with varying concentrations $\left(10^{-5}-10^{-8} \mathrm{M}\right)$ of $\mathrm{PGE}_{2}$ (Sigma Chemical Co.) at $37^{\circ} \mathrm{C}$ for $1 \mathrm{~d}$. In the same experiment, cloned DCs, MCs, and normal human skin fibroblasts from fetuses and two healthy individuals were also treated with $\mathrm{PGE}_{2}$. Morphological determination was examined by phase-contrast microscopy, and the culture supernatant was obtained and dialyzed against PBS for $24 \mathrm{~h}$ at $4^{\circ} \mathrm{C}$. 

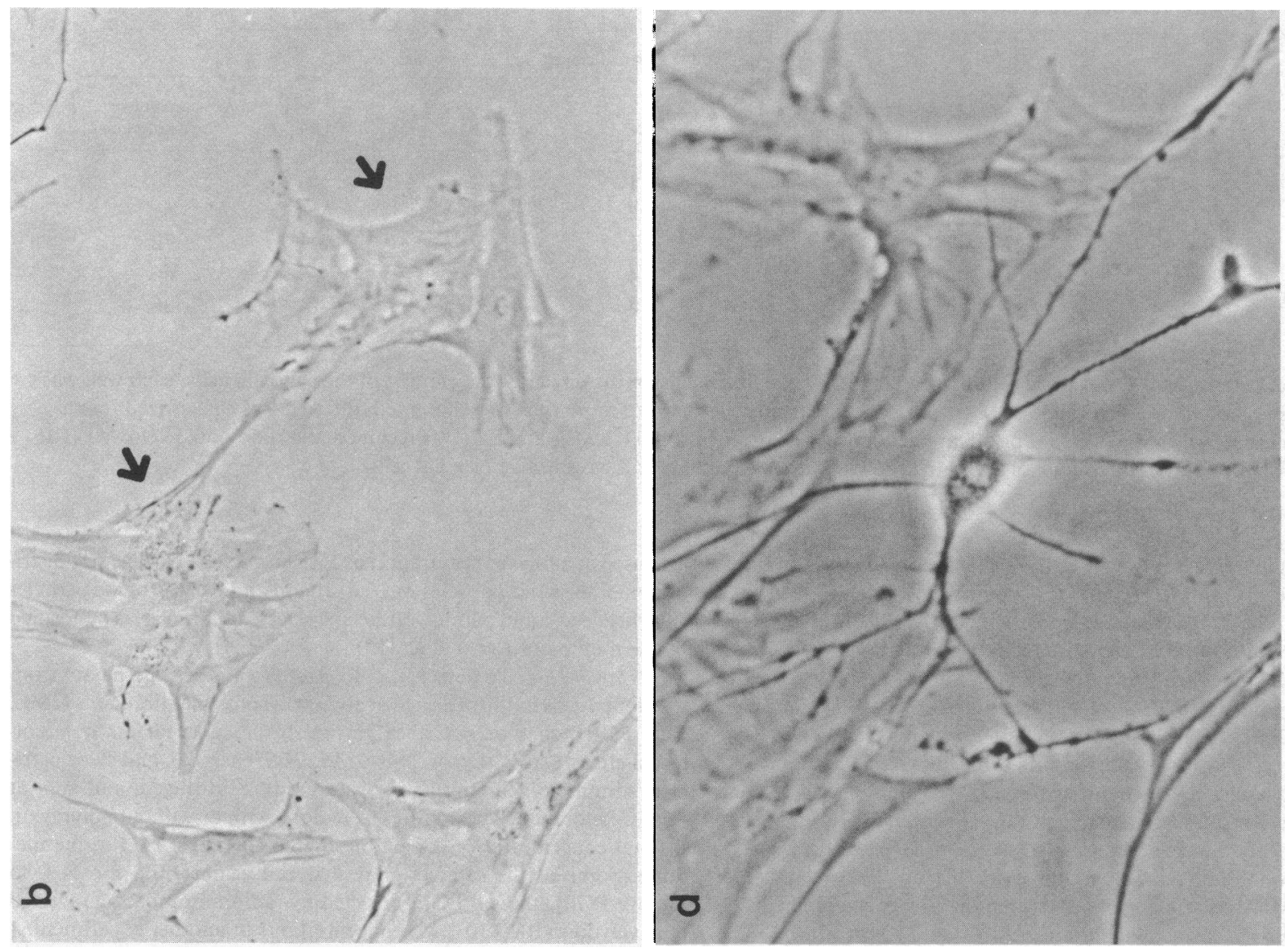

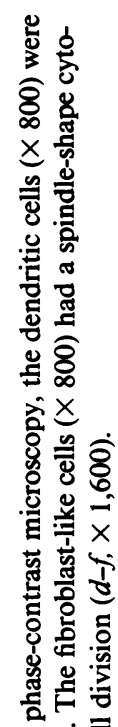
宙家 을 ก क

l. 를 究 ?

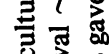
을 过
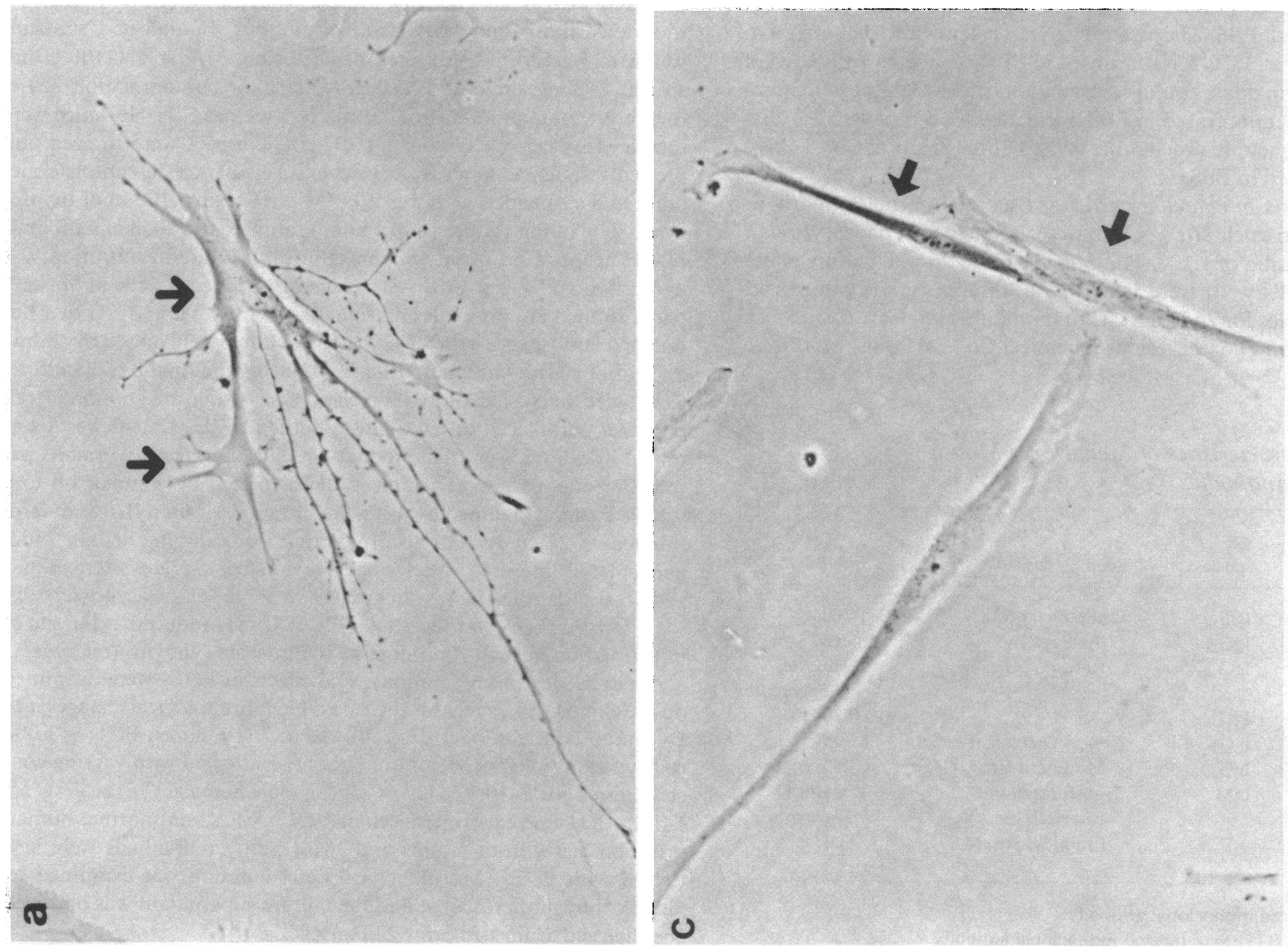

응 客

ఫิ

을

桴

ฮ छ

눙

ह

응 졍

윰

里

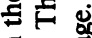

a $\dot{s}$

षै \&

㐘

글 흥

ธ。

응

⿷

:

跑.

要

ㄷㅇㅇ

幽

政

政

要

$\div$.

章毫

788 Goto et al. 

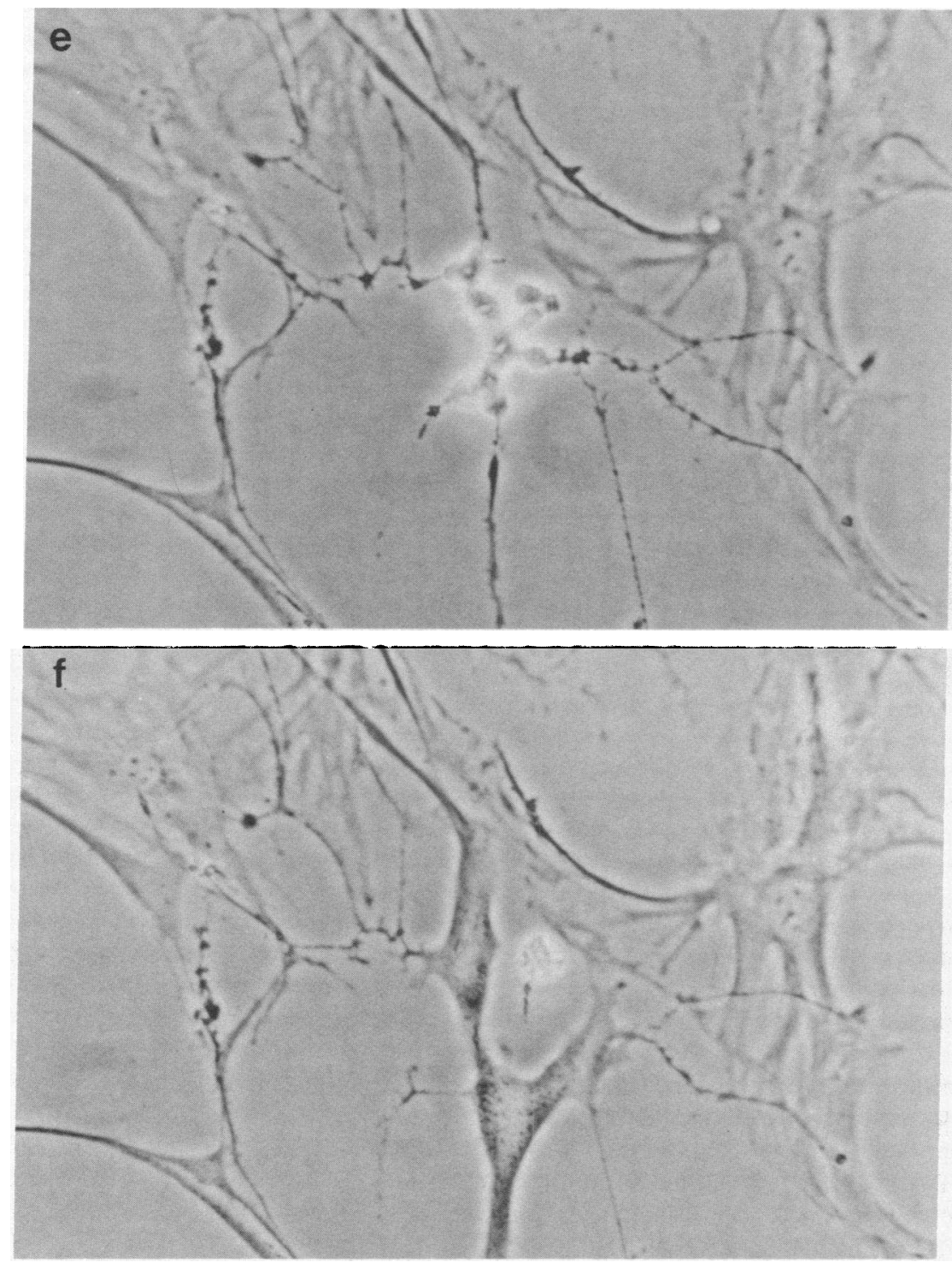

Figure 1. (Continued)

\section{Results}

Morphological characterization of the cloned synovial cells. As shown in Figs. $1 a-c$, the cloned synovial cells were basically categorized into three groups by morphology, although there were some intermediate conditions between them. Fig. $1 a$ shows the DCs (10) characterized by branched cytoplasmic extensions and numerous spherical phase-dense cytoplasmic granules. These cells were probably the same cell type that investigators called stellate (18) or interdigitating cells (19). The branched cytoplasmic extensions of the nearby cells were sometimes crossed. Time-lapse photographs showed cell division in DCs (Fig. $1 b-d$ ).

The MCs with an oval or rhombic shape had a dense and round nucleus (Fig. $1 e$ ). These cells are similar in appearance to type A synovial cells. Both the DCs and MCs grew very slowly; the doubling time being $\sim 5-7 \mathrm{~d}$.

The last category of synovial cells was the FCs with a spindle-shape nucleus and cytoplasm (Fig. $1 f$ ). These FCs grew rapidly (doubling time; roughly 1-2 d) took up a unidirectional arrangement in the in vitro culture and did not overlay each other. The FCs are similar in appearance to type B synovial cells (20). All the cloned cells were negative for nonspecific esterase staining after long-term culture, while MCs were positively stained only at a very early phase of the culture (20).

Results of adherent synovial cell cloning from the five RA patients is shown in Table I. In 1 to 11 out of 96 wells were DCs present and in 1 to 20 were MCs. In all instances, FCs were the dominant clones. Two synovial samples (Y.T. and M.N.) were recloned after $30 \mathrm{~d}$ of culture to assure that the cloned cells were actually the cloned DCs, MCs, or FCs. Each of the recloned cells showed the same morphological pattern as the respective original cells after 2 wk of recloning.

The three types of cloned synovial cells were cultured for up to $11 \mathrm{mo}$ (passage; roughly 10-20 times) without any significant morphological changes. However, this does not necessarily mean that one type of synovial cell could not be transformed to another type of cell. To test the possibility that the origin of the DCs may have been the synovial FCs, the cloned FCs were incubated with varying concentrations of $\mathrm{PGE}_{2}$. Within one day, about a third of the FCs had taken on a DC-like appearance, as shown in Fig. 2. The optimal dose of 


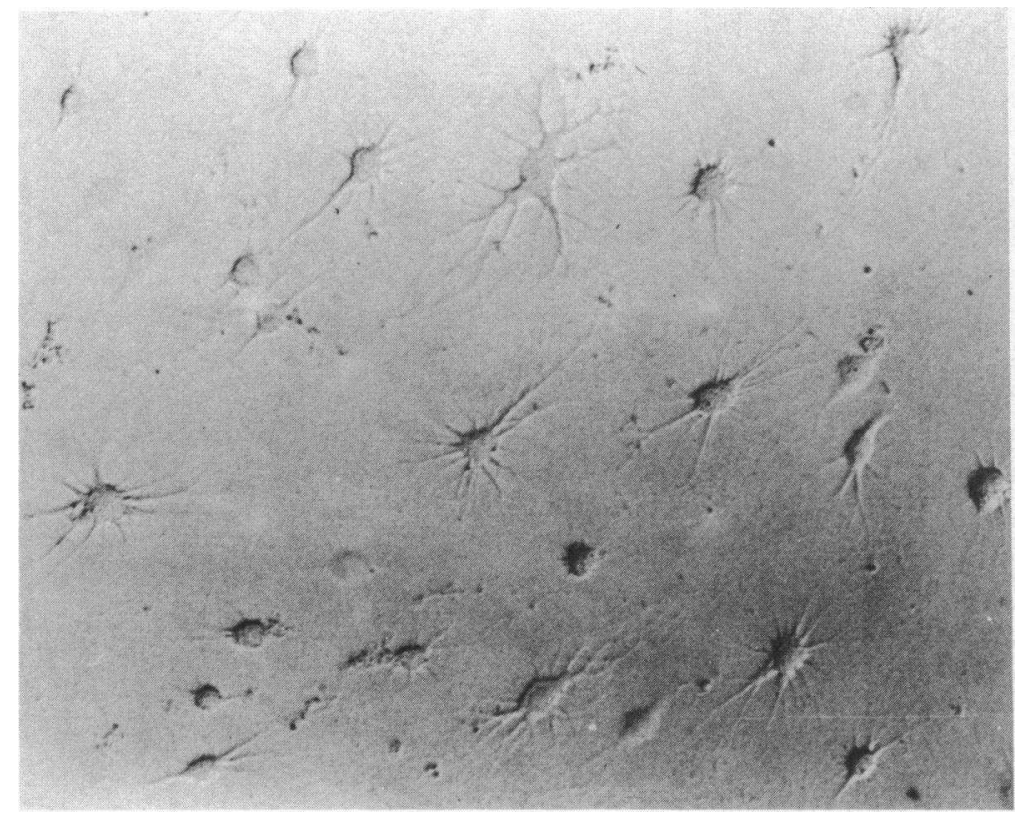

Figure 2. Fibroblast-like cells had turned into a dendritic cell-like appearance $(\times 400)$ after $24 \mathrm{~h}$ of treatment with $\mathrm{PGE}_{2}$.
$\mathrm{PGE}_{2}$ was $10^{-6} \mathrm{M}$. However, the DC-like cells reverted to the original FCs a few hours after the removal of $\mathrm{PGE}_{2}$ from the culture. $\mathrm{PGE}_{2}$ did not cause any morphological changes in MCs, DCs, or normal skin fibroblasts.

Immunofluorescence staining of the cloned synovial cells. The cloned synovial cells were stained with a larger panel of MoAbs as described in Table II. Characterization of the cloned synovial cells by immunofluorescence is summarized in Table III.

DCs were weakly reactive with antibodies to the $C_{3}$ bi receptor, $\left(\mathrm{OKM}_{1}\right.$ and Leu 15) (Fig. $\left.3 a, b\right)$, OKDR and antivimentin. DCs became strongly positive for OKDR when stimulated with $\gamma$-interferon (Fig. $3 c$ ). Neither $\mathrm{OKT}_{3}$ nor $\mathrm{OKB}_{7}$ MoAbs stained DCs. MCs were weakly reactive with monocyte MoAbs such as Leu $\mathrm{M}_{3}$ and OKM (Fig. $4 a, b$ ), OKDR and anti-vimentin MoAb. MCs were OKDR-positive when stimulated with $\gamma$-interferon (Fig. $4 c$ ) (21). FCs were only positive for anti-vimentin MoAb (Fig. $5 a$ ) (which is a characteristic marker for fibroblasts) and they became positive for OKDR after $\gamma$-interferon stimulation (Fig. $5 b$ ).

Phagocytosis of the cloned cells. As shown in Fig. 6, MCs phagocytosed a large number of charcoal particles (Fig. $6 a$ ), and FCs did so to a lesser degree (Fig. $6 b$ ), while neither DCs

Table III. Characterization of the Cloned Synovial Cells by MoAbs

\begin{tabular}{llll}
\hline MoAbs/cloned cells & DC & MC & FC \\
\hline OKDR & $\pm^{*}(+)^{ \pm}$ & $-(+)$ & $-(+)$ \\
Leu 15 & \pm & - & - \\
OKM $_{1}$ & \pm & \pm & - \\
Leu M & - & \pm & - \\
anti-Vimentin & \pm & \pm & + \\
OKT $_{3}$ & - & - & - \\
OKB $_{7}$ & - & - & - \\
\hline
\end{tabular}

\footnotetext{
* Indicates weak reactivity.
}

‡ Positive when stimulated with $\gamma$-interferon.
(Fig. $6 c$ ) nor DC-like cells transformed from FCs by $\mathrm{PGE}_{2}$ did (Fig. $6 d$ ).

IL-1-like activity in the culture supernatant from the cloned cells. The culture supernatants from the cloned cells in the absence of mitogens or stimulants were assayed for IL-1-like activity. As shown in Table IV, a relatively small number of DCs (30-50 cells) from different clones produced an IL-1-like factor (1-1.5 U/ml). Similarly, but to a lesser extent, both MCs and FCs secreted the IL-1-like factor spontaneously.

The IL-1-like activity in the culture supernatants from the cloned DCs, MCs, and FCs was dependent on the number of cells per well. From the approximate number of cells in the culture wells, the most efficient spontaneous producer of the IL-1-like factor was DC, followed by MC and FC. On a per cell basis, the DCs could produce the IL-1-like factor 10-30 times better than the FCs. The ability to produce IL-1-like factor by the cloned cells did not appear to be influenced significantly by cell passage because IL-1 activity was relatively constant in the supernatant from DCs, MCs, and FCs over months of culture. IL-1 activity was also produced by cloned cells that were cultured for $24 \mathrm{~h}$ in a medium free from FBS and $2 \mathrm{ME}$ or in a medium with polymyxin $\mathrm{B}$ to remove possibly contaminated lipopolysaccharides.

FCs produced the IL-1-like factor without stimulation. The DC-like cells transformed from FCs stimulated by $\mathrm{PGE}_{2}$ produced more IL-1-like factor than the original FCs (Table V). Normal skin fibroblasts cultured in the same medium neither released IL-1 factor spontaneously nor did they produce it after $\mathrm{PGE}_{2}$ stimulation (data not shown). There was no change in the number of cells throughout the experiments.

Silica particles are known to stimulate IL-1 release from monocytes (15). Cloned synovial adherent cells stimulated by silica particles produced 5 to 10 times more IL-1-like factor than resting cells (Table VI). Although DCs showed no apparent phagocytosis of charcoal particles (Fig. $6 c$ ), production of IL-1-like factor by DCs was nonetheless increased following incubation with charcoal, to levels comparable to those achieved following by silica particles (data not shown). FCs 

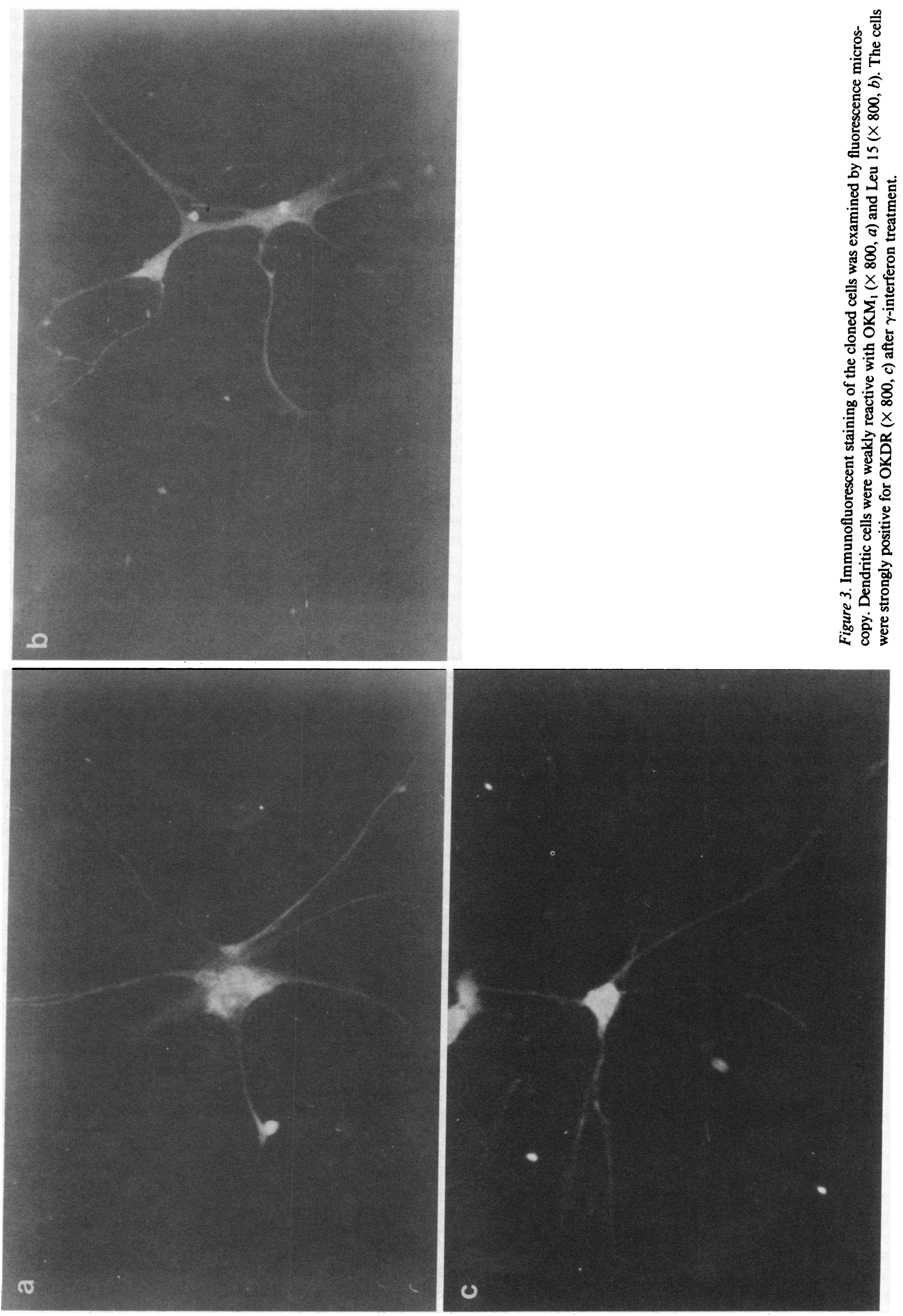

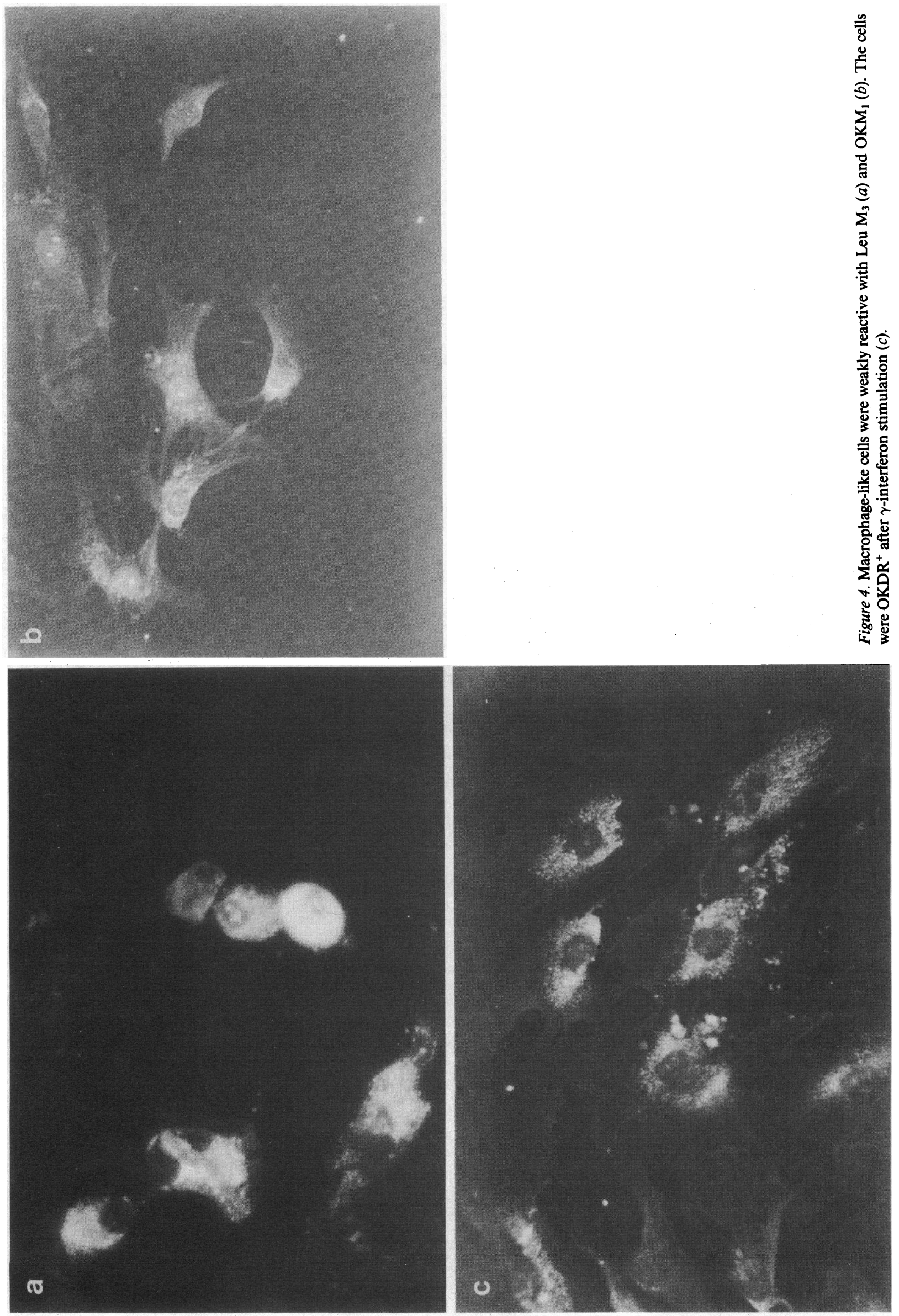

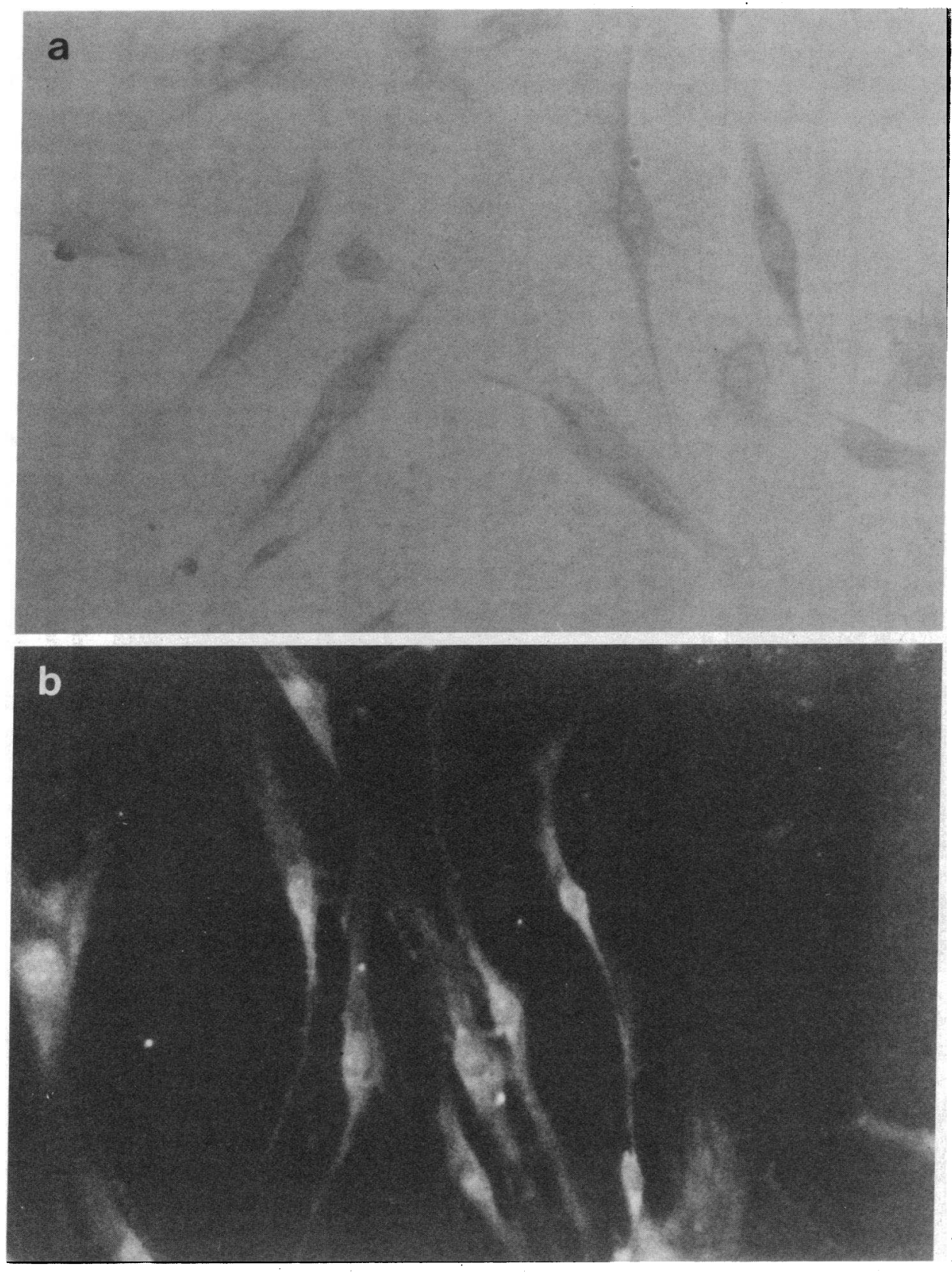

Figure 5. Fibroblast-like cells were positive for anti-vimentin $\mathrm{MoAb}(\times 800, a)$ and OKDR positive when treated with $\gamma$-interferon (b).

were the best responders to silica treatment in terms of IL-1like factor production. Silica did not affect the IL-1-like activity assay.

\section{Discussion}

Very few experiments on the long-term culture of synovial cells from patients with RA have been reported. Clarris et al. examined rheumatoid synovial cells from 24 RA patients and reported that, in most cases, cell lines could not be established from the rheumatoid primary cultures, and the lines that could be established were short lived (17-198 d) (22). In the present experiment, adherent synovial cells from RA patients were cloned and cultured for up to $11 \mathrm{mo}$. We still maintain $20 \mathrm{FC}$ clones out of 50 (see Table II: patient Y.T. plus M.N.), 1 DC clone out of 8 , and $1 \mathrm{MC}$ out of 32 clones. The reason why our synovial cells survived longer than others is unclear. It is possible that we selected long-lived cell lines. Alternatively, cloned cells may live longer than uncloned heterogeneous cells. More likely, the use of a cloning medium, HAM F12, favors the in vitro growth of synovial cells. The addition of $2 \mathrm{ME}$ may not be necessary, because DCs survived in a medium free from 2ME.

Three different types of synovial cells (FCs, MCs, and DCs) that have been cloned and characterized in the present experiments are represented in heterogeneous synovial cells $(18,19$, 23). Of the three major synovial cells, DCs have received particular attention as related to the pathogenesis of RA, because DCs express a large amount of Ia antigens on their surfaces, have a strong stimulatory activity in the autologous mixed leukocyte reaction, and produce a considerable amount of IL-1 (5-9). 


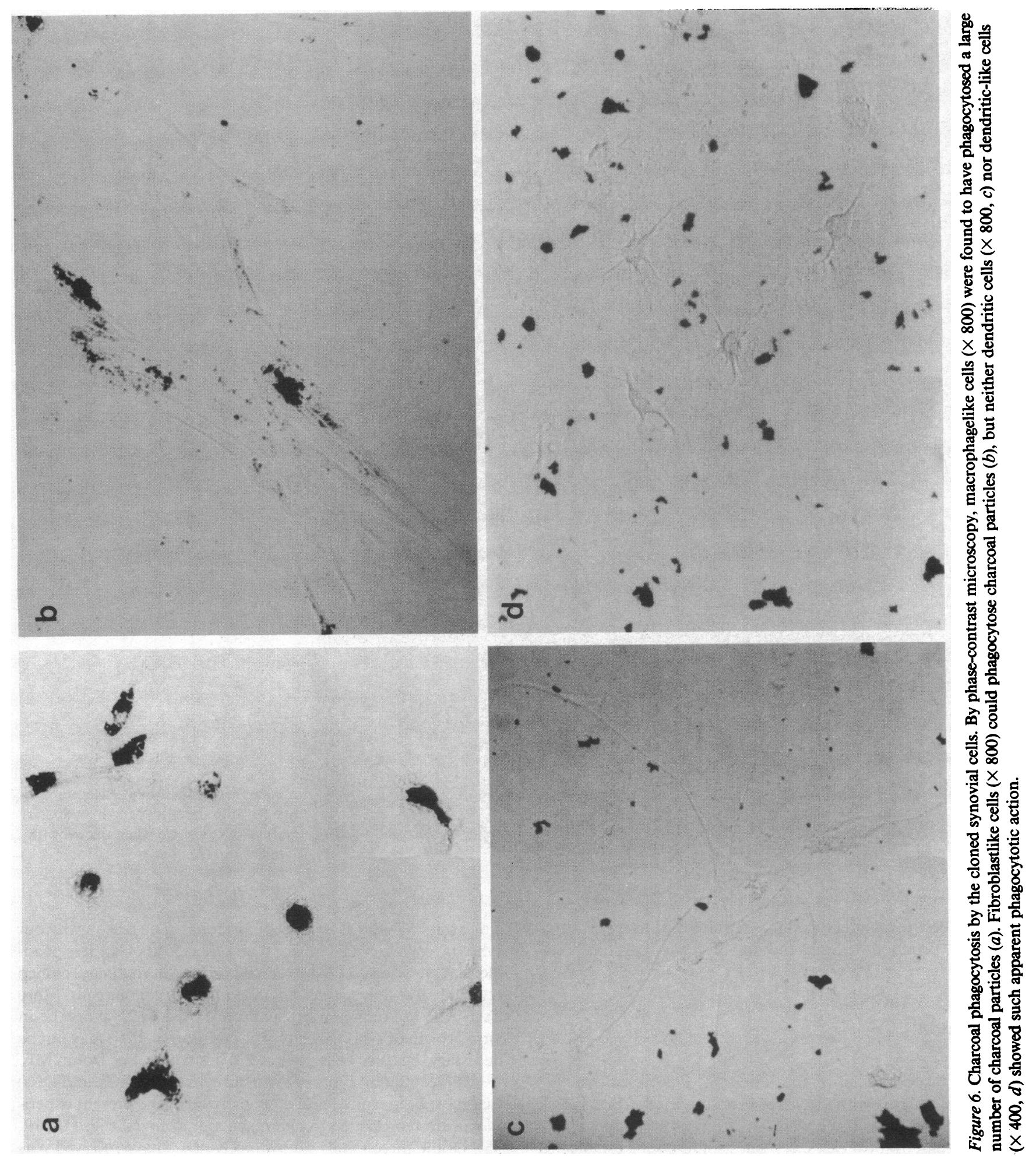


Table IV. IL-1-like Activity in the Supernatant from the Cloned Synovial Cells

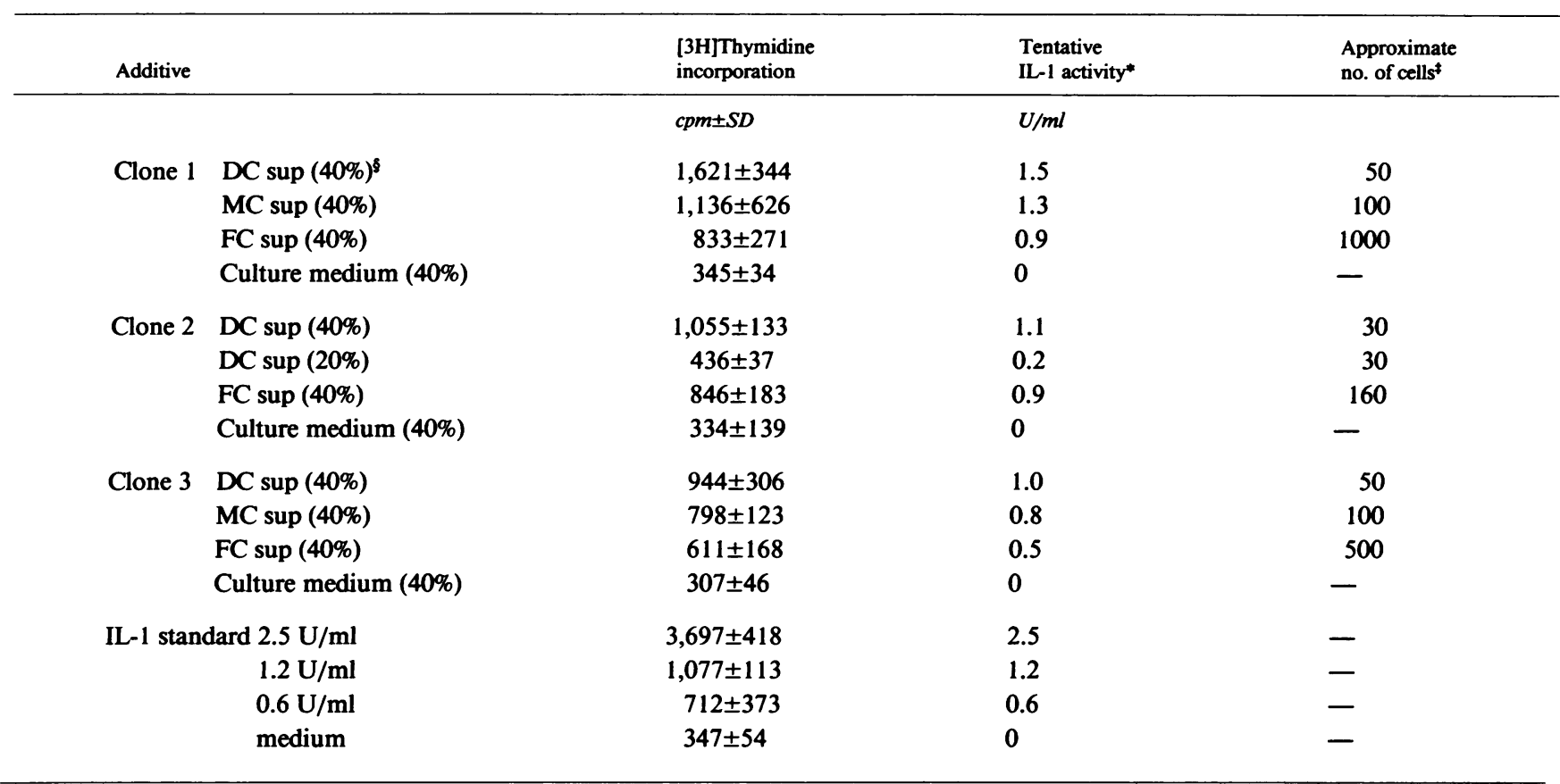

\footnotetext{
* The tentative IL-1 activity in units per milliliter was calculated by inserting the $\left[{ }^{3} \mathrm{H}\right]$ thymidine incorporation level (cpm) into the IL-1 standard proliferation curve described in the lower column. ${ }^{\ddagger}$ indicates the approximate number of cloned cells in the culture wells from which the supernatant was collected. $80 \mu \mathrm{l}$ of the culture supernatant sample from the cloned cell well was incubated with $100 \mu \mathrm{l}$ of thymocytes and $20 \mu \mathrm{l}$ of phytohemagglutinin to make the concentration of the samples $40 \%$, while $40 \mu \mathrm{l}$ of the sample $+100 \mu \mathrm{l}$ of thymocytes $+40 \mu \mathrm{l}$ of the medium $+20 \mu \mathrm{l}$ of phytohemagglutinin made the concentration of the samples $20 \%$.
}

The DCs take on a unique stellate or interdigitating appearance and may belong to a lineage similar to epidermal Langerhans cells or peripheral blood dendritic cells because these cells with a dendritic appearance are also Ia-positive and IL-1 producing cells and may be the principal accessory cell for antigen presentation to lymphocytes (1).

Some investigators have claimed that the precursor of DCs is the synovial FCs (11). However, these experiments were undertaken with heterogeneous synovial cell cultures, and it is difficult to draw any definite conclusion. In this study, the three cloned cell groups were morphologically distinct, but

Table V. IL-1-like Activity in the Supernatant from $P G E_{2}$-transformed DC-like cells

\begin{tabular}{llll}
\hline $\begin{array}{l}\text { Concentration } \\
\text { of } \mathrm{PGE}_{2}\end{array}$ & $\begin{array}{l}\text { DC-like } \\
\text { appearance* }\end{array}$ & $\begin{array}{l}{\left[{ }^{3} \mathrm{H}\right] \text { Thymidine }} \\
\text { incorporation }\end{array}$ & $\begin{array}{l}\text { Tentative IL-1 } \\
\text { activity }\end{array}$ \\
\hline$m o l$ & & $c p m \pm S D$ & $U / m l$ \\
$10^{-5}$ & + & $507 \pm 34$ & 0.4 \\
$10^{-6}$ & + & $830 \pm 131$ & 0.9 \\
$10^{-7}$ & + & $718 \pm 121$ & 0.7 \\
$10^{-8}$ & - & $483 \pm 23$ & 0.3 \\
0 & - & $474 \pm 56$ & 0.3 \\
& & &
\end{tabular}

* About a third of the cloned FCs were transformed into a DC-like appearance (indicated as + ). The number of cells did not change at all. * The tentative IL-1 activity in units per milliliter was calculated by inserting the $\left[{ }^{3} \mathrm{H}\right]$ thymidine incorporation level (cpm) into the IL-1 standard proliferation curve obtained in the same experiment. Before the IL-1 assay, the sample supernatant was dialyzed against a large volume of PBS overnight to remove $\mathrm{PGE}_{2}$. they had common characteristics, including production of an IL-1-like factor and Ia expression. The FCs showed a DC-like appearance during stimulation with $\mathrm{PGE}_{2}$ (Fig. 2). The DClike cells turned into the original FCs immediately after the removal of $\mathrm{PGE}_{2}$ from the culture. Although the FC and DClike conditions were interchangeable in our experiments, we don't know if the synovial FCs may be the precursors of DCs

Table VI. IL-1-like Activity in the Supernatant from the Silica-treated Cloned Cells

\begin{tabular}{llll}
\hline $\begin{array}{l}\text { Cloned cells* } \\
\text { (approximate } \\
\text { no. of cells/well) }\end{array}$ & $\begin{array}{l}\text { Treatment } \\
\text { with } \\
\text { silica }\end{array}$ & $\begin{array}{l}{\left[^{3} \mathrm{H}\right] \text { Thymidine }} \\
\text { incorporation }\end{array}$ & $\begin{array}{l}\text { Tentative IL-1 } \\
\text { activity }\end{array}$ \\
\hline & & $c p m \pm S D$ & $\mathrm{U} / \mathrm{ml}$ \\
$\mathrm{DC}(50)$ & - & $769 \pm 113$ & 0.4 \\
& + & $4,722 \pm 608$ & 3.3 \\
MC $(1,000)$ & - & $1,779 \pm 253$ & 1.2 \\
& + & $8,957 \pm 1,535$ & 6.5 \\
FC $(3,000)$ & - & $1,280 \pm 177$ & 0.7 \\
& + & $9,552 \pm 1,784$ & 6.7 \\
\hline
\end{tabular}

* DC: dendritic cell, MC: macrophage-like cell, FC: fibroblastlike cell. Approximate number of cells per well is indicated in parentheses. \# The cloned cells were treated with $100 \mu \mathrm{g} / \mathrm{ml}$ of silica particles for $24 \mathrm{~h}$ at $37^{\circ} \mathrm{C}$. The supernatants were collected for IL-1 assay.

${ }^{3}$ The tentative IL-1 activity in units per milliliter was calculated by inserting the $\left[{ }^{3} \mathrm{H}\right]$ thymidine incorporation level (cpm) into the IL-1 standard proliferation curve obtained in the same experiment. 
and be transformed into DCs under the influence of inflammatory substances, including $\mathrm{PGE}_{2}$, produced in chronic synovitis.

From studies in progress we would question whether these synovial cells are unique to rheumatoid synovium, since the synovial cells from other joint diseases such as osteoarthritis and gouty arthritis have been cloned and three types of cells (DCs, FCs, and MCs) were cloned from both the above conditions in a fashion similar to RA. These cells, however, did not spontaneously produce IL-1-like factor (manuscript in preparation). These three types of synovial cells may not be unique to RA, but may be found in other arthritides. However, the functional characteristics or differentiation (or activation) stages of these cells in RA may differ from other forms of synovtis.

It is striking that the majority of the rheumatoid synovial cells, regardless of morphology, produced the IL-1-like factor spontaneously even after long-term culture. It is not certain at present whether the IL-1-like factor released from the cloned cells was identical to IL-1 itself. Methods are now available to test the possibility directly, and such studies are in progress.

This is the first long-term culture of clonal rheumatoid synovial cells. They consist of three different cell types and these cells spontaneously secrete an IL-1-like factor in longterm culture. If the synovial DCs, MCs, and FCs release an IL-1-like factor in the rheumatoid synovium, it would be of interest to clarify the activity of this signal and the role of these cells in the pathophysiology of the rheumatoid joint.

\section{Acknowledgments}

We would like to thank Dr. Nathan J. Zvaifler, UCSD Medical Center, Dr. Dennis A. Carson, Scripps Clinics and Research Foundation, and Dr. Kayo Inaba, Kyoto University, for fruitful discussions.

This work was supported in part by the Japan Research Foundation for Clinical Pharmacology.

\section{References}

1. Harris, E. D. 1985. Pathogenesis of rheumatoid arthritis. In Textbook of Rheumatology. W. N. Kelley, E. D. Harris, S. Ruddy and C. B. Sledge, editors. W. B. Saunders Company, Philadelphia. 886-915.

2. Dayer, J. M., and S. Demezuk. 1984. Cytokines and other mediators in rheumatoid arthritis. Springer Semin. Immunopathol. 7:387413.

3. Dayer, J. M., B. Rochemonteix, B. Burrus, S. Demczuk, and C. A. Dinarello. 1986. Human recombinant interleukin 1 stimulates collagenase and prostaglandin $\mathrm{E}_{2}$ production by human synovial cells. J. Clin. Invest. 77:645-648.

4. Dayer, J. M., M. L. Stephenson, E. Schmidt, W. Karge, and S. M. Krane. 1981. Purification of a factor from human blood monocyte-macrophages which stimulates the production of collagenase and prostaglandin $E_{2}$ by cells cultured from rheumatoid synovial tissues. FEBS (Fed. Eur. Biochem. Soc.) Lett. 124:253-256.

5. Kuntzcrow, M., and H. G. Kunkel. 1982. Human dendritic cells: Major stimulator of the autologous and allogeneic mixed leukocyte reactions. Clin. Exp. Immunol. 49:338-346.

6. Zvaifler, N. J., R. M. Steinman, G. Kaplan, L. L. Lau, and M. Rivelis. 1986. Identification of immunostimulatory dendritic cells in the synovial effusions of patients with rheumatoid arthritis. J. Clin. Invest. 76:789-800.

7. Waalen, K., J. Thoen, Ø. Førre, T. Hovig, J. Teigland, and J. B. Natvig. 1986. Rheumatoid synovial dendritic cells as stimulators in allogeneic and autologous mixed leukocyte reactions-comparison with autologous monocytes as stimulator cells. Scand. J. Immunol. 23:233-241.

8. Janossy, G., G. Panayi, O. Duke, M. Bofill, L. W. Poulter, and G. Goldstein. 1981. Rheumatoid arthritis: A disease of T-lymphocyte/ macrophage immunoregulation. Lancet. ii:839-842.

9. Duff, G. W., O. Forre, K. Waalen, E. Dickens, and G. Naki. 1985. Rheumatoid arthritis synovial dendritic cells produce interleukin-1. Br. J. Rheum. 24 (Suppl. 1):94-97.

10. Woolley, D. E., E. D. Harris, C. L. Mainardi, and C. E. Brincherhoff. 1978. Collagenase immunolocalization in cultures of rheumatoid synovial cells. Science (Wash. DC). 200:773-775.

11. Hendler, P. L., P. E. Lavoie, Z. Werb, J. Chan, and W. E. Seaman. 1985. Human synovial dendritic cells. Direct observations of transition to fibroblasts. J. Rheumatol. 12:660-664.

12. Waldman, H., and I. Lefkovits. 1984. Limiting dilution analysis of cells of the immune system II: What can be learnt? Immunology Today. 5:295-298.

13. McGarrity, G. J., and D. A. Carson. 1982. Adenosine phosphorylase-mediated nucleoside toxicity: Application toward the detection of mycoplasma infection in mammalian cell cultures. Exp. Cell. Res. 139:199-207.

14. Goto, M., and N. J. Zvaifler. 1983. Characterization of the killer cell generated in the autologous mixed leukocyte reaction. $J$. Exp. Med. 157:1309-1323.

15. Koski, I. R., P. G. Poplack, and R. M. Blaese. 1968. A nonspecific esterase stain for the identification of monocytes and macriphages. In Methods in Cellular Immunology. B. R. Bloom and J. R. David, editors. 359-367. Academic Press, New York.

16. Luger, T. A., B. M. Stadler, B. M. Luger, B. J. Mathieson, M. Mage, J. A. Schmidt, and J. J. Oppenheim. 1982. Murine epidermal cell-derived thymocyte activating factor resembles murine interleukin-1. J. Immunol. 128:2147-2152.

17. Miyasaka, N., N. Murota, K. Yamaoka, K. Sato, T. Yamada, T. Nishido, and M. Okuda. 1986. Interleukin-2 defect in the peripheral blood and the lung in patients with Sjogren's syndrome. Clin. Exp. Immunol. 65:497-505.

18. Krane, S. M. 1981. Aspects of the cell biology of the rheumatoid synovial lesion. Ann. Rheum. Dis. 40:433-448.

19. Duke, O., G. S. Panayi, G. Janossy, and L. W. Poulter. 1982. An immunohistological analysis of lymphocyte subpopulations and their microenvironment in the synovial membranes of patients with rheumatoid arthritis using monoclonal antibodies. Clin. Exp. Immunol. 49:22-30.

20. Edwards, J. C. W. 1982. The origin of type A synovial lining cells. Immunobiology. 161:227-231.

21. Amento, E. P., A. K. Bhan, K. G. McCullagh, and S. M. Krane. 1985. Influences of gamma interferon on synovial fibroblast-like cells. Ia induction and inhibition of collagen synthesis. J. Clin. Invest. 76:837-848.

22. Clarris, B. J., J. R. E. Fraser, and J. Ferguson Stanley. 1981. Some in-vitro comparisons of synovial cells dispersed by trypsin from rheumatoid and non-rheumatoid synovium. Ann. Rheum. Dis. 40:286-292.

23. Burmester, G. R., A. Dimitriu-Bona, S. J. Waters, and R. J. Winchester. 1983. Identification of three major synovial lining cell populations by monoclonal antibodies directed to Ia antigens and antigens associated with monocytes/macrophages and fibroblasts. Scand. J. Immunol. 17:69-82. 